\title{
A further evaluation of the sperm length in aleocharines (Coleoptera Staphylinidae)
}

\begin{abstract}
Observations on 8 species allowed to extend the known range: the new minimum and maximum values are respectively $100 \mu \mathrm{m}$ for Aleochara intricata Mannerheim and $3.000 \mu \mathrm{m}$ for Heterota plumbea (Waterhouse). Evaluations for most species were carried out either on spermatozoa separated from the spermatheca or on bundles extracted from testes. Sperm length of Atheta inquinula was supposedly assumed as corresponding to that of the vasa deferentia. Conclusive diagrams show sperm length in some species to be disproportionate if compared with the size of the receptacle.

Riassunto - Ulteriore valutazione della lunghezza degli spermatozoi nelle aleocarine (Coleoptera Staphylinidae)

Valutata precedentemente su 7 specie, la gamma del carattere in questione era 150-2.300 $\mu \mathrm{m}$. Una valutazione su altre 8 specie ha fatto registrare un nuovo valore minimo e un massimo, rispettivamente di $100 \mu \mathrm{m}$ in Aleochara intricata Mannerheim e $3.000 \mu \mathrm{m}$ in Heterota plumbea (Waterhouse). Come in precedenza, le misurazioni sono state effettuate su singoli spermatozoi estratti dalla spermateca, oppure su fascetti di spermatozoi estratti dai testicoli. Nel caso di Atheta inquinula (Gravenhorst), non è stato tecnicamente possibile ottenere una valutazione diretta, e si suppone che la lunghezza degli spermatozoi sia di circa $1.500 \mu \mathrm{m}$, cioè corrispondente a quella dei dotti deferenti. Come già visto in precedenza, gli spermatozoi di una parte delle specie esaminate sono smodatamente lunghi in confronto con le dimensioni del ricettacolo.
\end{abstract}

Key words: new range, exceeding sperm length.

\section{INTRODUCTION}

A previous evaluation of the character "sperm length" in 7 species the subf. Aleocharinae allowed to register a range from 150 to $2.300 \mu \mathrm{m}$ (De Marzo, 2008). An evaluation on further 8 species of the same subfamily allows to extend this range in both its minimum and maximum values.

Most species have been identified thanks to Dr. Adriano Zanetti (Verona Natural History Museum). 


\section{MATERIAL AND METHODS}

Names of the examined species are listed in Tab. A; they agree with the checklists of Ciceroni et al. (1995) and Smetana (2004), except for Atheta mucronata (Kraatz), which has been more recently revised by Feldmann (2007). Four specimens at least were examined for females and males of each species; they were killed with ethyl acetate vapours and dissected in physiological salt solution $(\mathrm{NaCl} 0,9 \%)$. Measures were taken with graduated eye-piece and 40x phase-contrast lens on spermathecae or testes compressed on slides in the same solution. The first evaluation was attempted on spermatozoa isolated the mass extracted from compressed spermathecae. Then, evaluation was attempted on sperm bundles extracted from the testicular follicles.

Parts of the spermatheca are designated according to De Marzo (2009a; 2009b).

\section{RESULTS}

Spermathecal anatomy in the species examined here agrees with the rule in the aleocharines, as spermatheca includes: (a) a receptacle sclerotized to some extent and provided with a compressor muscle; (b) a long duct, which usually exhibits a lower sclerotization degree; (c) a gland connected with the receptacle. Usually, duct contains only a very poor number of spermatozoa, as Aleochara tristis (Fig. 1.A); otherwise, it is occluded by a spermatophore, as in Aleochara intricata (Fig. 1.B), and is therefore filled with a dense mass of sperm.

Length of spermatozoa was found comparatively low in the nominal genus Aleochara, where it ranges from 100 to $1.000 \mu \mathrm{m}$ (Table A), and wasn't therefore difficult to be evaluate on female material. The same material was suitable also to measure the very short spermatozoa of Atheta coriaria $(320 \mu \mathrm{m})$ and Caloderina hierosolymitana $(200 \mu \mathrm{m})$.

Tab. A - Sperm length (microns) in the examined aleocharines. Evaluations were carried out either on spermatozoa isolated from the spermatheca (material from females) or on sperm bundles extracted from testis (material from males). In the case of Atheta inquinula sperm length does supposedly correspond to that of the vasa deferenttia.

\begin{tabular}{|l|c|c|}
\hline \multicolumn{1}{|c|}{ Species } & Material from females & Material from males \\
\hline Aleochara bipustulata (Linnaeus) & 1.000 & \\
\hline Aleochara intricata Mannerheim & 100 & \\
\hline Aleochara tristis Gravenhorst & 500 & \\
\hline Atheta coriaria (Kraatz) & 320 & 1.100 \\
\hline Atheta mucronata (Kraatz) & & 1.500 (supposed) \\
\hline Atheta inquinula (Gravenhorst) & & \\
\hline Caloderina hierosolymitana (Saulcy) & 200 & 3.000 \\
\hline Heterota plumbea (G. Waterhouse) & & \\
\hline
\end{tabular}




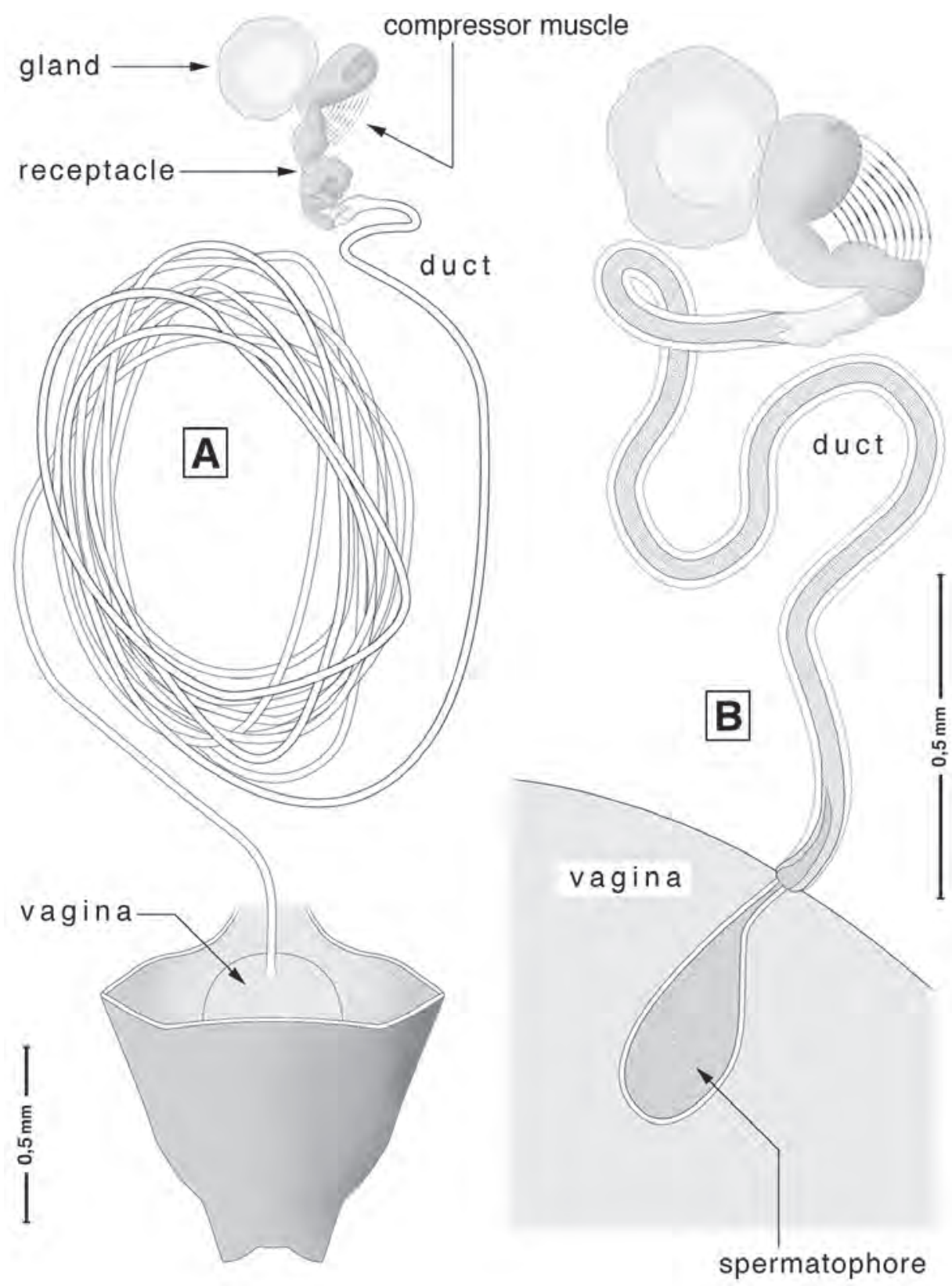

Fig. 1 - Spermathecal features suggesting of the two different insemination modalities known in Aleocharinae: A, duct adapted to a very long endophallic filament in Aleochara tristis Gravenhorst; $\mathrm{B}$, duct occluded by a spermatophore in Aleochara intricata Mannerheim. 


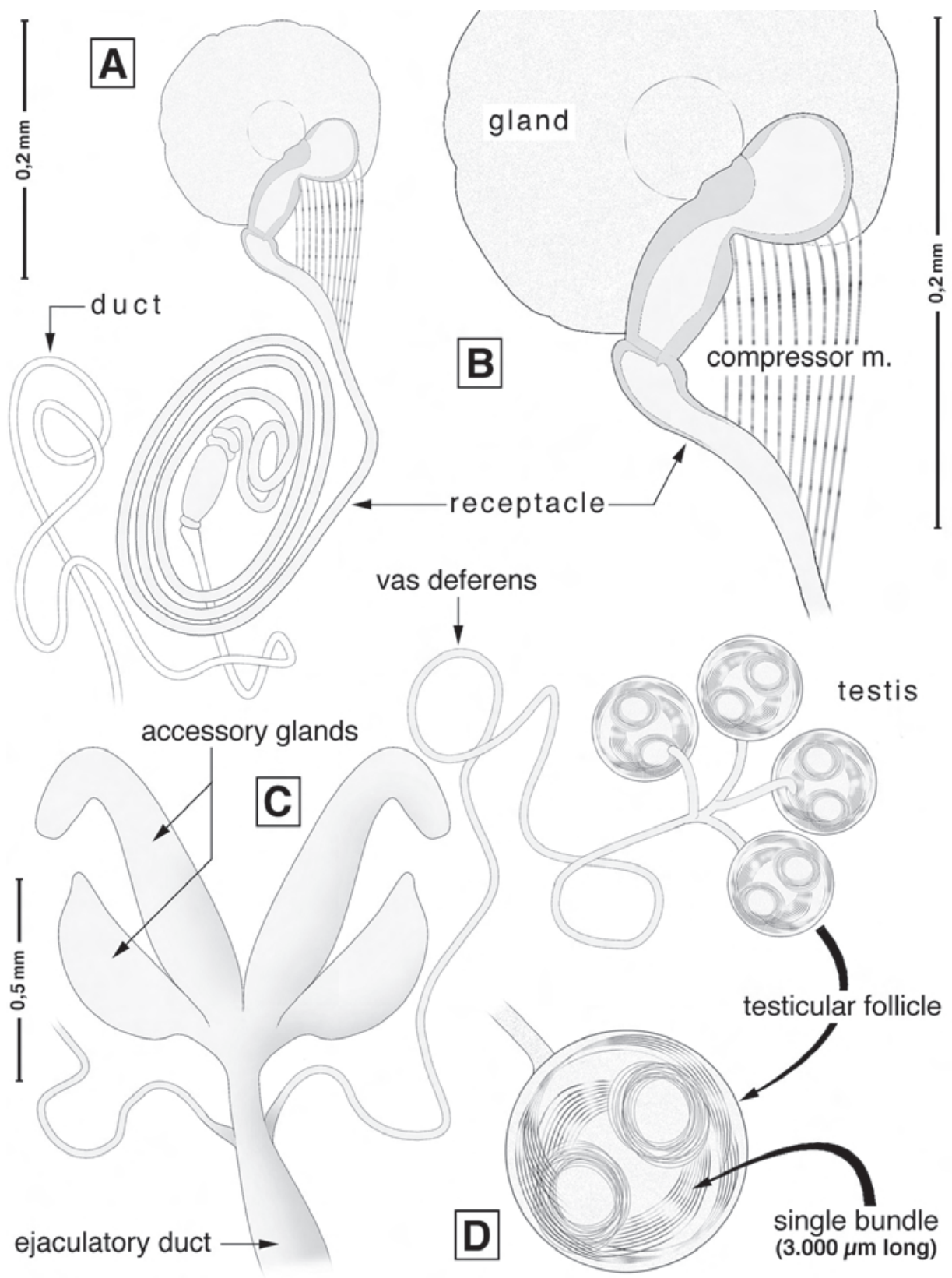

Fig. 2 - Heterota plumbea (Waterhouse): details of female/male internal genitalia. 

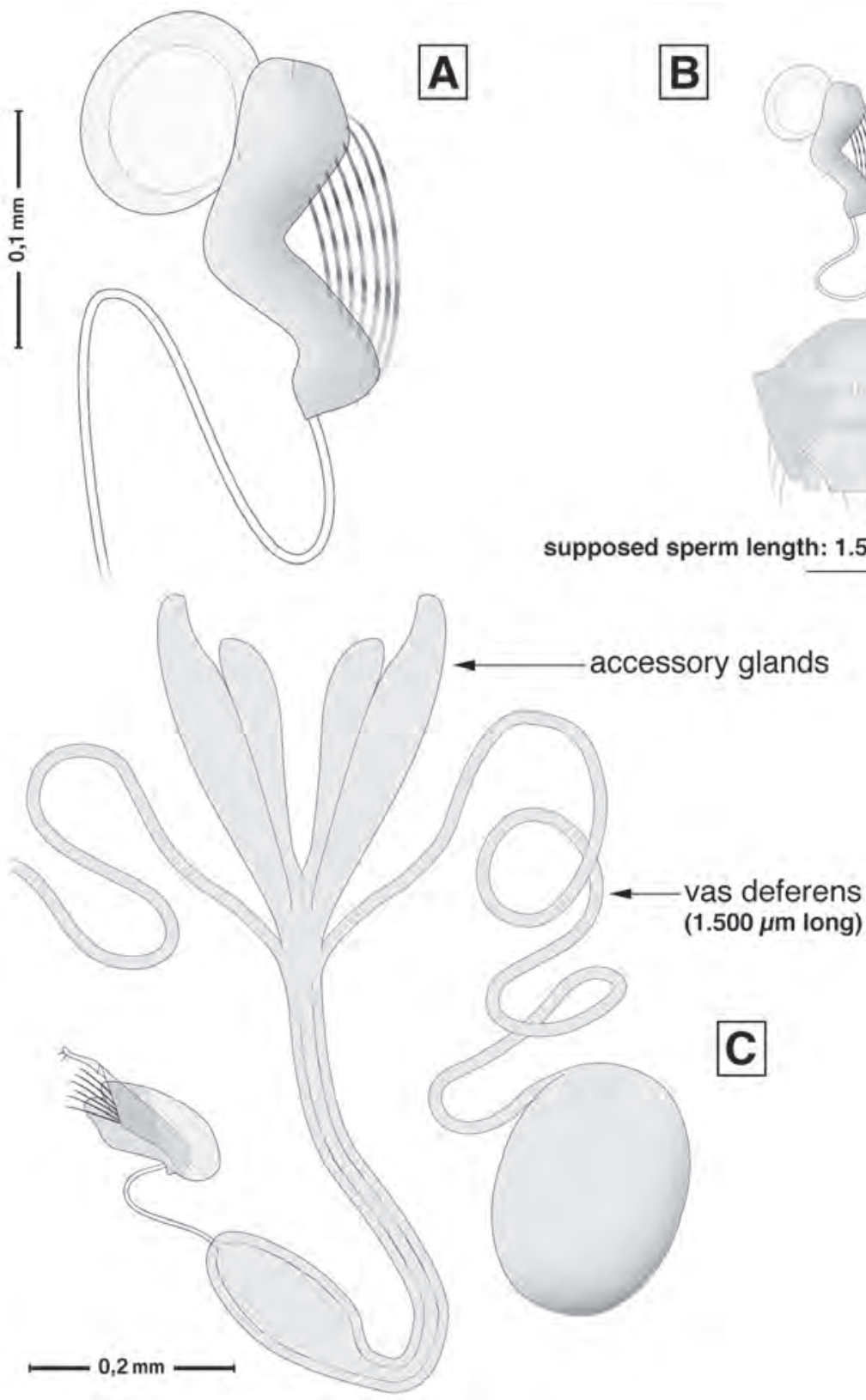

supposed sperm length: $1.500 \mu \mathrm{m}$
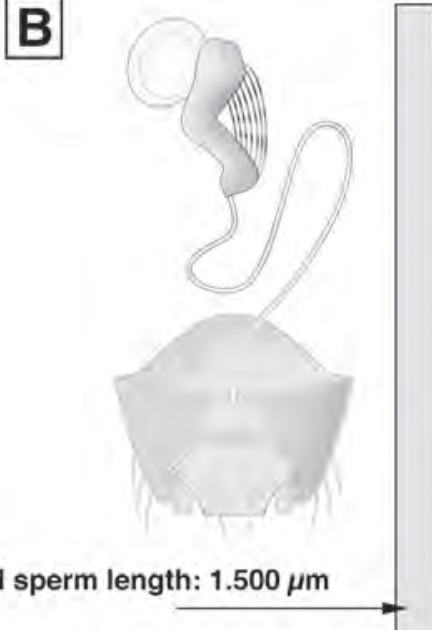


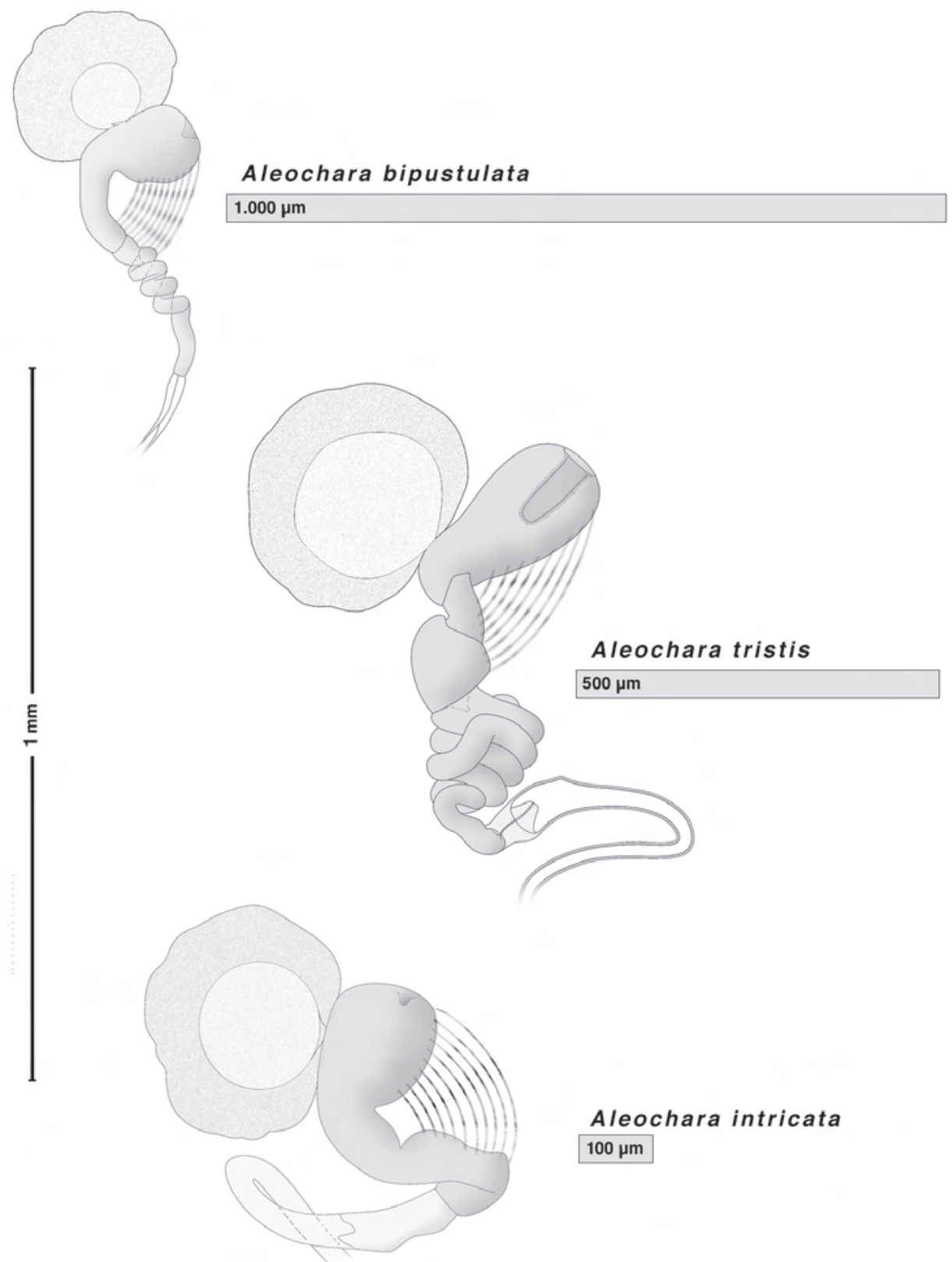

Fig. 4 - Examined species of the genus Aleochara: sperm length compared at the same magnification with the size of their receptacle. 
Atheta coriaria

$350 \mu \mathrm{m}$

\section{Atheta mucronata}

\section{$1.100 \mu \mathrm{m}$}

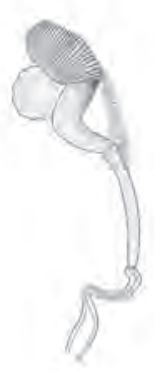

Caloderina yierosolimitana

$200 \mu \mathrm{m}$

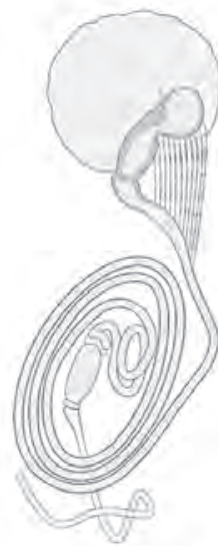

\section{Heterota plumbea}

$3.000 \mu \mathrm{m}$

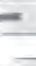

$1 \mathrm{~mm}$

Fig. 5 - Other examined aleocharines: sperm length compared at the same magnification with the size of their receptacle. 
Higher values of sperm length were appreciated on male material, by isolating bundles from the testicular follicles of Atheta mucronata $(1.100 \mu \mathrm{m})$ and Heterota plumbea $(3.000 \mu \mathrm{m})$. Attempts to obtain separate spermatozoa of these species were unsuccessful, as their spermathecae contained a very intricate mass of sperm.

Both female and male materials were not suitable to evaluate sperm length in the case of Atheta inquinula, as spermathecae provided only an intricate sperm mass and testicular follicles didn't contain clear sperm bundles. Supposedly, the spermatozoa of this species are $1.500 \mu \mathrm{m}$ long as the vasa deferentia (Fig. 3).

\section{CONCLUSIVE REMARKS}

This new evaluation does extended the known range of the character "sperm length" in aleocharines at both its minimum and maximum values. These are respectively 100 and $3.000 \mu \mathrm{m}$.

As elsewhere observed (De Marzo, 2008), sperm length of some species looks somewhat disproportionate if compared with the size of the receptacle. This is especially evident for Aleochara bipustulata, Atheta mucronata and Heterota plumbea (Figs. 3-4). Because spermatozoa of this species do bend two or more times to enter receptacle, the question "how these very long spermatozoa can go away from the receptacle to fertilise eggs?" comes again.

\section{BIBLIOGRAFIA}

Ciceroni A., Puthz V., Zanetti A., 1995 - Coleoptera Polyphaga III. Staphylinidae. - In: Minelli A., Ruffo S., La Posta S. (eds.), Checklist delle specie della fauna italiana, Calderini ed., Bologna, fasc. 48, 65 pp.

De Marzo L., 2008 - Lunghezza degli spermatozoi rilevata in alcune aleocarine (Coleoptera Staphylinidae). - Boll. Zool. agr. Bachic., Milano, ser. II, 40 (1): 1-8.

De MARzo L., 2009a - Biodiversità della spermateca nei Coleotteri. - Atti Accademia Nazionale Italiana di Entomologia, anno LVI (2008): 69-96.

De Marzo L., 2009b - Aspetti morfologici della spermateca in Diestota guadalupensis Pace e altre Aleocharinae (Coleoptera Staphylinidae). - Entomologica, Bari, 40 (2006-2007): 57-73.

Feldmann B., 2007 - On the identity of Atheta mucronata (Kraatz 1859) (Coleoptera: Staphylinidae,

Aleocharinae). - Linzer biol. Beitr., 39: 57-63.

Smetana A., 2004 - Staphylinoidea. - In: Löbl I. \& Smetana A. (eds), Catalogue of Palaearctic Coleoptera, vol. 2, Apollo Books, 942 pp.

LuIGI De MARzo, via F. Turati 3, I-70016 Noicàttaro (BA), e-mail: 1.demarzo@alice.it 